\title{
ОСНОВНІ ПРИНЦИПИ ТА ПОЛОЖЕННЯ ІНДИВІДУАЛЬНОЇ РОБОТИ СТУДЕНТА ПРИ НАВЧАННІ ЗА КРЕДИТНО-МОДУЛЬНОЮ СИСТЕМОЮ 3 ДИСЦИПЛІНИ “ГІСТОЛОГІЯ, ЦИТОЛОГІЯ ТА ЕМБРІОЛОГІЯ”
}

\author{
Т. М. Бойчук, Л. Я. Федонюк, А. А. Ходоровська
} Буковинський державний медичний університет, Чернівці

\section{MAIN PRINCIPLES AND REGULATIONS OF STUDENT'S INDIVIDUAL WORK DURING STUDYING BY THE CREDIT-MODULAR SYSTEM ON THE DISCIPLINE "HISTOLOGY, CYTOLOGY AND EMBRIOLOGY"}

\author{
T. M. Boychuk, L. Ya. Fedoniuk, A. A. Hodorovska \\ Bukovynian State Medical University, Chernivtsi
}

\begin{abstract}
У статті розглядаються особливості навчання за кредитно-модульною системою у Буковинському державному медичному університеті, зокрема основні принципи та положення індивідуальної роботи студента 3 дисципліни "Гістологія, цитологія і ембріологія".

In the article there are considered the peculiarities of the studying by the credit-modular system in Bukovynian State Medical University, in particular the main principles and regulations of student's individual work on the discipline "Histology, Cytology and Embriology".
\end{abstract}

Вступ. Підписавши Болонську конвенцію, Україна підтвердила наміри наслідувати міжнародні стандарти організації навчального процесу та мати можливість входження в Європейський освітньо-науковий простір.

На сьогодні Буковинський державний медичний університет (БДМУ) здійснює модернізацію сучасної вищої освіти шляхом розширення використання новітніх освітніх і педагогічних технологій у межах Болонського процесу.

Основна частина. На кафедрі гістології, цитології та ембріології БДМУ навчання за кредитно-модульною системою проходить відповідно до основних їїположень та принципів ібазується на основних положеннях та принципах, до яких належать: кредитність; модульність; методичне консультування; організаційна динамічність; гнучкість та партнерство; пріоритетність змістової й організаційної самостійності та зворотного зв'язку між студентом і викладачем; науковість та прогностичність; технологічність та інноваційність; усвідомлення перспектив.

Програма $з$ дисципліни "Гістологія, цитологія та ембріологія” для студентів спеціальності “Лікувальна справа" структурована на три модулі, до складу кожного з яких входить по два змістових модулі. На вивчення дисципліни відводиться 285 навчальних го- дин (9,5 кредитів ECTS), з них 40 годин припадає на лекції, 130 годин - на практичні заняття та 116 годин на самостійну роботу студентів, причому, самостійна робота складає в середньому $40 \%$ від загального обсягу навчального навантаження студента. Для студентів спеціальності “Стоматологія" дисципліна включає два модулі, на вивчення яких відводиться 210 навчальних годин (7 кредитів ECTS), з них 20 годин припадає на лекції, 120 годин - на практичні заняття та 70 годин - на самостійну роботу студентів.

В умовах кредитно-модульної системи навчання студента передбачає оцінювання кожного виду навчальної діяльності студента в межах модуля. Оцінювання є бальним і займає питому частку у підсумковій оцінціз дисципліни. Оцінка за поточну навчальну діяльність визначається з урахуванням оцінок поточного контролю практичних занять та балів за виконання студентом індивідуальної роботи. Загальна оцінка за модуль визначається як сума балів за поточну навчальну діяльність та балів, які студент отримав при складанні підсумкового контролю засвоєння модуля.

Індивідуальна робота студента (IPC) $€$ невід'ємною складовою частиною кредитно-модульної системи організації навчального процесу, яка дає можливість не лише контролювати рівень знань та вмінь студентів, але й регулювати, коректувати та управляти

(ㄱ Т. М. Бойчук, Л. Я. Федонюк, А. А. Ходоровська 